\title{
Teachers' Responsibility for Effective Learning Environment
}

\author{
Muhammad Talat ${ }^{1 *}$, Kamal Haider ${ }^{2}$, Shagufta Shahzadi ${ }^{3},{ }^{4}$ Dr.Maroof Bin Rauf ${ }^{5}$ Waqar Ahmed \\ ${ }^{1}$ Lecturer, Department of Education, University of Loralai, Pakistan, \\ ${ }^{2}$ Asst. Prof. Chairman Department of Education (Abdul Haq Campus) Federal Urdu University of Arts, \\ Science and Technology Karachi, Pakistan, \\ ${ }^{3}$ Prof Faculty of Education, University of Karachi, Pakistan, \\ ${ }^{4}$ Asst. Prof Faculty of Education, University of Karachi, Pakistan, \\ 5Research Scholar, Department of Education, University of Karachi, Pakistan
}

\begin{abstract}
Teachers' role in any system of education is the back boon of development for any country and effective teaching should be expected for these teachers. A teacher is a symbol of honesty with his noble profession with kind caring and supportive attitude towards the successful transferring knowledge even the unsuitable circumstances and limited resources. Teaching according to the needs and modern requirements always remain on top priority for the honest and hardworking teacher, therefore, one can say the adjustment quality is the best skill for the teacher must be suited for any types of situations. The population of the study comprised of 150 teachers and students from private and government schools located in Karachi. A Likert scale has been used comprising 10 items; the data were analyzed through the chi-square test by the used of SPSS. All null hypotheses have been rejected. The results clearly showed that the teachers' honesty, skills, training, and good salary packages are supportive ingredients for their efficiency.
\end{abstract}

Key words: Teachers, Responsibility, Effective, Learning, Environment 


\section{$2^{\text {nd }}$ International Conference on Research in \\ TEACHING and EDUCATION}

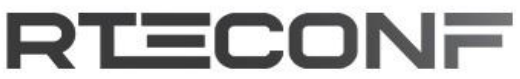

6-8 March, 2020

BUDAPEST,HUNGARY

\section{Introduction}

The main difference between developed and under developing countries is to the relocation of tasks a developed country gives full intentions towards the educational goals of the decay through the strong mechanism of teaching and learning environment. In poor countries the intentions almost towards the good governess and financial resources even the teaching and learning can be considered as a top priority. A teacher not only transfers knowledge to the students but he or she makes the thing brighter for them through the golden principles of morality to become an active member of the nation. In most recent philosophy the common mechanism is the same for all which is free from the religion. In poor countries like Pakistan, India, Sri Lanka, Bangladesh etc. good governance is the major issue for the ruling government. Teachers' strong relations defiantly produce strongly influence students' character building and every teacher's method of teaching and efforts slightly change to others and naturally the moral attitude also different that should leave unforgettable memories in students' future or say till the end of life. That is why the teachers' responsibilities for the academic, mental, moral and physical development of the students are very important.

\section{Objectives}

a) To find out the opportunities available for teachers in educational institutions.

b) To analysis the learning opportunities of students through teaching.

c) To find out the intellectual creativity for the students through class learning.

d) To find out the students' achievements through effective teaching methods

\section{HYPOTHESES}

There will be no significant relation between teachers' responsibility and effective learning environment

\section{Conceptual Framework}

Teachers' responsibility to the preparation of students for future social and moral role in the society is the essential element of the teaching, during classroom teaching teacher prediction towards the future achievements and developing students' moral character can be seen on the back of the image projection screen (Taylor 1964). The social aspect of students' development is a strong predictor 


\section{$2^{\text {nd }}$ International Conference on Research in TEACHING and EDUCATION}

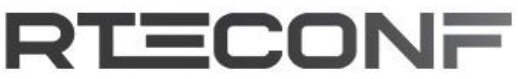

6-8 March, 2020 BUDAPEST,HUNGARY

for future success through with a polished moral and responsible individual should be produced for the society through proper guidelines and instructions by a teacher (Sternberg, 1998). Today in this world people are defiantly realizing the importance of teachers' contribution towards the improvement quality atmosphere where the students' participation in education and learning process should be considered as an act of polishing hidden students' talents for future hard and competitive time which leads to the foundation of true future professional with sound and balanced personality . Through neuroscience teaching and learning can provide better solutions of the related issues and the effectiveness of these teaching and learning up to the use of research findings for the teachers (Bruer, 1997). The teachers' role for students' mentally, academically and physically development is undeniable fact for those who consider teacher as the payee of the services provider for their kids but actually a producer and director for the screen projection of students' beautiful images. The potential and an honest teacher always remain his responsibilities on top priority in his diary, he is the lever of mechanism which rotates for the production of future leaders like good politician, scientist. engineers, doctors, managers etc. The reason of increasing numbers of problems in poor and under redeveloping countries is low economics level and less productive social activities especially less amount available for education, these problems can be identified through educational neuroscience (Howard, Pickering, Diack, 2007). The teachers' services, especially in underdeveloped countries, need to be maximized under stress and low financial benefits even supported huge family expenditures but the totally different scenario in the developed countries where teachers look quite comparable as the financial and economic condition is concerned. The students' mental and physical development starts right from the prior solid professional education it is the primary school level which leads to the good students and good sportsman for the rest of school's duration because the college level than university level is considered the finishing educational period almost called career entrance gate, so naturally the students' mainly focusing their future task but participating in colleges' and universities' academic, social and sports activities prepare them to use the skills in more competitive future careers and professionals tasks. The teachers' provide new effective methods of learning and 


\section{$2^{\text {nd }}$ International Conference on Research in TEACHING and EDUCATION}

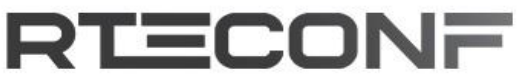

6-8 March, 2020 BUDAPEST,HUNGARY

teaching not only in classroom teaching but in deferent frames of activities because the monitor always showing the capturing images in deferent angles through teachers' eye called camera and the effectiveness of conceptual teaching and learning process is one of the suitable examples of mentally and academically development measures ( Ischebeck, et al., 2006). The career and counseling guidance programs will help students under the supervision of true expert and professional teachers by collecting the future related thoughts for the selection of professions and the teacher who releases the importance of the chosen field according to the future demands, hardness of the particular field, professional and employment opportunities available for the country of origin and the rest of the world, The most important thing is to evaluate the whole personality under the capabilities, strength and weakness and of course teacher is a best evaluator More key issues during teaching and learning process can be resolved through philosophical way of teaching and the major difference between teachers one who know the philosophy of education and one who use old traditional methods is internal skills and feelings as he know that its his national responsibility (Noddings \& Nel, 1995). The teachers' own stagey according to the need of students always shows very productive results through taken youthcentered initiatives, consideration and realistic their feelings and emotion (Ghorbal, 2011). The use of more advanced methods especially use of technology now bring some changes in teaching and learning process which shows that young talented future leaders are growing for the nation (Wang, Myers \&Yanes, 2010. The talented and responsible teachers always try to use full sketch skills of their students, the sports and other extra time activities like sports and others are the real ways for mentally and physically students' development so naturally these teachers motivate and encourage them to participate in these activities (Lazarin, 2011). The teachers"' role for the development of students' moral attitude and character also a huge task need to be accomplished through hard working and observing powers and the institutional support is mandatory for further steps of students' better achievements (Whitt \& Blimling, (2000), The students' participation in co-curricular activities can polish hidden skills and talents more effectively even the lessons of tolerance etc, for the future adjustment and uneven period of time (Van\&Ahuja, 2011). The mental and physical development 


\section{$2^{\text {nd }}$ International Conference on Research in TEACHING and EDUCATION}

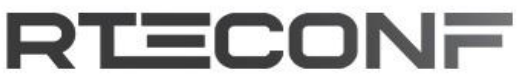

6-8 March, 2020 BUDAPEST,HUNGARY

in participation of sports is a unique way to show their potential and field and the proper teachers' instructions lead to the foundation of strong talented young man a real gift for the nation (Ellis et al., 2013). Teachers attitude likely to flexible almost at every shape of their duties and responsibilities not in particular institution but out form the premises by adjustment of some others students for assigns tasks for the good students for the reports of some problems creating students to correct them and pull them in a way of development (Lindholm (2012), he teachers' tremendous work can be appreciated by an organization some additional programs can be allowed or permitted for the improvement of students' progress along some more sports, seminars, workshops etc. (George, 2012). The feature of the whole stagey in classroom teaching depend learning capability and strength of the academic level of the students which can be affected through better transfer of knowledge methods and a teacher who designed the course contents with suitable easy steps for efficient outcomes with complete organization support. The problem-based learning can be solved through proper judgment of student's current and previous progress reports and these past experiences can be lighted for the corrections of weakness and strengthen their powers for understanding the difficult phenomenon. The things can be seen more difficult not longer sustain this difficulty through proper teaching and learning process ((Harris, Lowery, \& Farrow, 2008). The people who engage hospitality professions like hotels, airlines, dealing officials need more positive and pleasant attitude during their duties a teacher prepare his students for the event and uneven bounces of their lives naturally morality leads everyone and those students who participating both academics and outclass programs can rotates their style if they join these professions (Rust, et al., 2010). The teacher should obey constructivism steps for more effective learning process presented by Jean Piaget through which background knowledge which help them to combine all internal strength for the development of new structure of students' future tasks ( Bodner, Klobuchar \& Geelan, 2001). The globalization of this advanced grow the importance of communication skills in this scenario schools and colleges even universities should promote the healthy activities side by side the academic activities the discussions programs in the shapes of competitions during flexible time, seminars and workshops can improve students internal skills and remove hesitation in front of people will make them perfect for future leadership roles (Salter 


\section{$2^{\text {nd }}$ International Conference on Research in \\ TEACHING and EDUCATION}

RTECDNF

6-8 March, 2020

BUDAPEST,HUNGARY

et al., 2010). he feature of the whole stagey in classroom teaching depend learning capability and strength of the academic level of the students which can be affected through better transfer of knowledge methods and a teacher who designed the course contents with suitable easy steps for efficient outcomes with complete organization support. the problem of teaching particularly those students who belong to the lower class families and having huge pressure for better adjustment in this society almost creates some pressure on teachers also because the main responsibility belongs to them is to convert knowledge to make students successful. The teacher's qualifications not enough for them to make them successful teacher, there are some skills and qualities with dignity of work mandatory to influences their personality to make them unique. During school life the students like to play games more than the study time, sometime teacher give them flexibility to use their subject's period as a free period if he realizes that the students look tied after the continues period of time but it does not mean that the importance transferred towards the sports instead of study it not be happened every time. The teachers' flexibility for the effective learning is important and mandatory as all knows that teacher act as a mentor for the creation of bright students' future for the leadership role and positions even harder and computable period of time a head that is why the demand of quality education asking true professional and devoted teachers especially for the under loping countries where the teachers not getting huge amount of money for their services but they like to share their full commitment that they can be punctuated for the development of their respective countries (Kleibard, 2004).

\section{Research Methodology}

This study based on survey both qualitative and quantitative approached has been used for collection data. The population of the study consisted of all the teachers of colleges in Karachi; A questionnaire consisting of relevant items was developed. For analysis of data chi-square was used through SPSS for proper result 


\section{$2^{\text {nd }}$ International Conference on Research in}

TEACHING and EDUCATION
Rॄ=CONF

6-8 March, 2020

BUDAPEST,HUNGARY

\section{Table 1}

Testing of Chi-square $(\mathrm{N}=150)$

\begin{tabular}{|c|c|c|c|c|c|c|c|c|}
\hline Items & $\begin{array}{l}\text { Strongly } \\
\text { Disagree }\end{array}$ & Disagree & Undecided & $\begin{array}{l}\text { Strongly } \\
\text { Agree }\end{array}$ & Agree & $\begin{array}{l}\text { Expected } \\
\text { Frequency }\end{array}$ & $\begin{array}{l}\text { Chisquare } \\
\text { Test } \\
\quad\left(\chi^{2}\right)\end{array}$ & $\begin{array}{l}\mathrm{H}_{0} \\
\text { Rejected } \\
\text { Accepted }\end{array}$ \\
\hline $1-$ & 44 & 18 & 5 & 9 & 74 & 30 & $111.600^{\mathrm{a}}$ & Rejected \\
\hline $2-$ & 6 & 34 & 5 & 8 & 97 & 30 & $218.333^{\mathrm{a}}$ & Rejected \\
\hline $3-$ & 45 & 9 & - & 75 & 2 & 30 & $75.013^{a}$ & Rejected \\
\hline 4- & 5 & 15 & 49 & 19 & 62 & 30 & $78.533^{a}$ & Rejected \\
\hline $5-$ & 50 & 24 & 5 & 55 & 21 & 30 & $24.453^{\mathrm{a}}$ & Rejected \\
\hline 6- & 16 & 56 & 19 & 42 & 17 & 30 & $43.533^{\mathrm{a}}$ & Rejected \\
\hline $7-$ & 2 & 1 & - & 1 & 146 & 30 & $416.567^{a}$ & Rejected \\
\hline 8 & 38 & 32 & - & 58 & 21 & 30 & $20.400^{\mathrm{a}}$ & Rejected \\
\hline 9- & 19 & 41 & 41 & 33 & 18 & 30 & $18.833^{\mathrm{a}}$ & Rejected \\
\hline $10-$ & 34 & 10 & - & 17 & 28 & 30 & $64.027^{\mathrm{a}}$ & Rejected \\
\hline
\end{tabular}

\section{Description}

Referring to table of $\chi^{2}$, the tabulated $\chi^{2}$ values with $\mathrm{df}=4$ at $\alpha=0.05$ is smaller than the calculated values; hence the Ho is rejected in all the cases. 


\section{$2^{\text {nd }}$ International Conference on Research in}

TEACHING and EDUCATION
Rॄ=CONF

6-8 March, 2020

BUDAPEST,HUNGARY

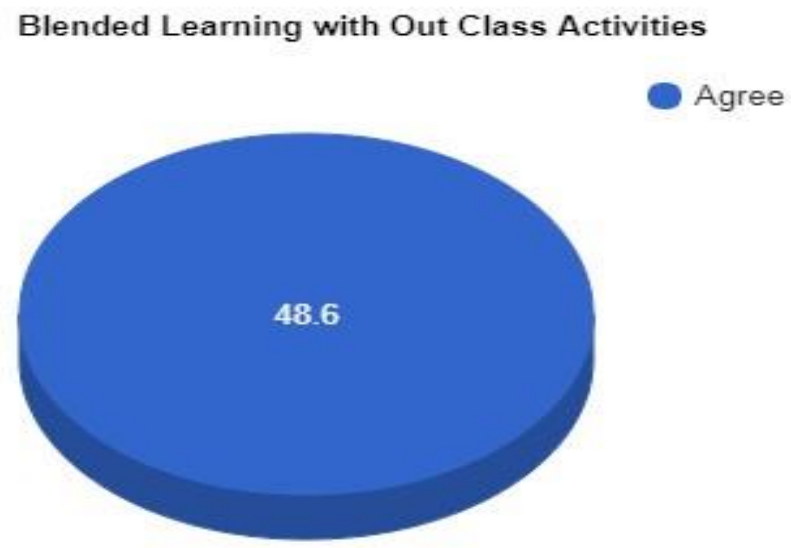

\section{Conclusion}

This study provides the valid information about the true and unique character of teachers who are an integral part of education and learning process. The teachers' characteristics should be counted during classroom teaching not only higher qualification to influence their whole performances and efficiency, there are some extra skills and qualities required to delivered full flash knowledge to the students even harder and uneven circumstances. The delivery of good knowledge can be affected the whole personality of the students and the teachers' enthusiasm, honesty, skills, punctuality, periodicity are the parameters for the successful professional career as a teacher. The teachers' strategies towards the transferring knowledge with nice and pleasant manner always are counted for the prosperity of the nation. The character building process always works during the entire period of study for a student and the teachers not only deliver the knowledge but his work can be extended out of the institutional premises. The teachers are the pillars of the nations and the latest development in science and technology is a result of the good educational structure of the advanced countries in this world which changed the whole scenario of this world.

\section{References}

Bodner, G., Klobuchar, M., \& Geelan, D. (2001). The many forms of constructivism. Journal of Chemical Education, 78, 1107-1134. 


\section{$2^{\text {nd }}$ International Conference on Research in TEACHING and EDUCATION}

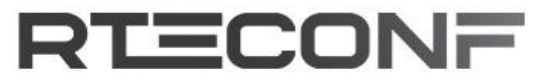

6-8 March, 2020 BUDAPEST,HUNGARY

Bruer, J.T., (1997). "Education and the brain: A bridge too far". Educational Researcher. 26-16 Ellis, G., et al (2013). Better Behaviour through Home-School Relations: Using valuesbased education to promote positive learning. Routledge.

Ghorbal, B. I., (2011). The role of middle management in the execution expansion strategies: The case of developers' selection of hotel projects. International Journal of Hospitality Management, 30(2), 272-282.

Harris, S., Lowery-Moore, H., \& Farrow, V. (2008). Extending Transfer of Learning Theory to Transformative Learning Theory: A Model for Promoting Teacher Leadership. Theory Into Practice, 47(4), 318-326.

Howard-Jones, P; Pickering, S.; Diack, A (2007). "Perception of the role of neuroscience in education. Summary Report for the DfES Innovation Unit"

Kleibard, H. (2004). Scientific curriculum-making and the rise of social efficiency. In The Struggle for American Curriculum (pp. 77-105).

Lazarin, M., (2011)."Federal Investment in Charter Schools" (PDF). Institute of .

Education .Sciences.Center for American Progress.Retrieved 2 October 2015. Lindholm-

Leary, K. (2012). Success and challenges in dual language education. Theory into Practice, 51(4), 256-262.

Noddings, Nel (1995). Philosophy of Education. Boulder, CO: Westview Press. p. 1. ISBN 0-8133-8429-X

Rust, et al., (2010).Rethinking marketing. Harvard BusinessReview, 88(1), 94-101. Salter, et al., (2010). Virtual communication, transformational leadership, and implicit leadership. Journal of Leadership Studies, 4(2), 16

Steinberg,N. R. (2011). An Inquiry into Science Education, Where the Rubber Meets the Road Rotterdam : Sense Publisher. 
$2^{\text {nd }}$ International Conference on Research in TEACHING and EDUCATION
RECONF

6-8 March, 2020

BUDAPEST,HUNGARY

Wang, L., Myers, D., \&Yanes, M. (2010). Creating student-centered learning experience through the assistance of high-end technology in physical education. Journal of Instructional Psychology, 37(4), 352-356.

Whitt, E. J. \&Blimling, G. S. (2000). Applying professional standards and principles of good .practice in student affairs. San Francisco, CA: Jossey-Bass Publishers..

(2nd Ed.) pp. 612-628. 